Int. J. Electrochem. Sci., 12 (2017) $8708-8732$

\title{
Mild Steel Corrosion Inhibition by Benzotriazole in 0.5M Sulfuric Acid Solution on Rough and Smooth Surfaces
}

\author{
M. Amini ${ }^{1}$, M. Aliofkhazraei ${ }^{1, *}$, A.H. Navidi Kashani ${ }^{2}$, A. Sabour Rouhaghdam ${ }^{1}$ \\ ${ }^{1}$ Department of Materials Engineering, Tarbiat Modares University, P.O. Box: 14115-143, Tehran, Iran \\ ${ }^{2}$ School of Metallurgy and Materials Engineering, College of Engineering, University of Tehran. \\ *E-mail: maliofkh@gmail.com, khazraei@ modares.ac.ir
}

doi: $10.20964 / 2017.09 .70$

Received: 19 April 2017 / Accepted: 22 July 2017 / Published: 13 August 2017

\begin{abstract}
The corrosion inhibition of benzotriazole in $0.5 \mathrm{M}$ sulfuric acid solution is evaluated on the mild steel specimens with two amounts of surface roughness. Benzotriazole adsorption on mild steel surface followed Langmuir isotherm. The corrosion inhibitor has generally physisorption on both surfaces. The results obtained by the different experimental methods showed good agreement with each other. Results of FTIR test showed a peak related to C-H bond for both surfaces as a proof of the presence of benzotriazole on the steel's surface which its intensity was higher for rough surface because of more adsorption of corrosion inhibitor on the surface.
\end{abstract}

Keywords: Benzotriazole, Corrosion, Mild Steel, Roughness, Sulfuric Acid.

\section{FULL TEXT}

(C) 2017 The Authors. Published by ESG (www.electrochemsci.org). This article is an open access article distributed under the terms and conditions of the Creative Commons Attribution license (http://creativecommons.org/licenses/by/4.0/). 